\title{
Two Distinct Mechanisms of Interleukin-2 Gene Expression in Human T Lymphocytes
}

\author{
Car1 H. June,` Kelly M. Jackson, ` Jefirey A. Ledbetter $\dagger$ \\ Jeffrey M. Leiden, $\ddagger$ Tullia Lindsten $\ddagger$ and Craig B. Thompson $\ddagger$ \\ *Naval Medical Research Institute, Bethesda, MD 20814, USA; †Oncogen \\ Corporation, Seattle WA 98121 , USA; $\ddagger$ Howard Hughes Medical Institute, and \\ Departments of Medicine and Microbiology/Immunology, University of Michigan, \\ Ann Arbor, $M I$ 48109, USA
}

Interleukin-2 (IL-2) gene regulation was investigated in primary cultures of highly purified human peripheral blood $\mathrm{CD}^{+}{ }^{+} \mathrm{T}$ cells. Two discrete mechanisms for induction of $T$-cell proliferation could be distinguished by examining cell cycle progression and the expression of the IL-2 gene. Stimulation of cells by CD3 MoAb induced only transiently expressed, small amounts of IL-2 mRNA that was completely suppressed by cyclosporine. Costimulation of T cells with CD3 MoAb and either CD28 MoAb or PMA, but not calcium ionophore, induced a 50-100-fold increased in IL-2 gene expression and secretion. High levels of IL-2 gene expression could also be achieved by stimulation with calcium ionophore and PMA or CD28 MoAb and PMA, but not by CD28 MoAb plus calcium ionophore. IL-2 gene expression and T-cell proliferation induced by CD3 MoAb plus PMA or calcium ionophore plus PMA were completely suppressible by cyclosporine. In contrast, IL-2 gene expression and T-cell proliferation induced by CD28 MoAb plus PMA were unaffected by cyclosporine. The CD28 signal was dependent on new protein synthesis. Nuclear run-on transcription assays showed that anti-CD28 did not affect lymphokine transcription. A major effect of CD28 stimulation on mRNA stability was shown by studies using actinomycin D; CD28 stimulation substantially increased the halflife of IL-2 and TNF-alpha mRNA. The effects of anti-CD28 stimulation were specific for growth factors, and thus differ from previously described effects of cycloheximide on mRNA stability. These studies suggest the existence of two biochemical pathways for the induction of $11-2$ production, one that occurs at the transcriptional level and is mediated by intracellular calcium release and protein kinase $C$ and is cyclosporine-sensitive, and one that acts post-transcriptionally, is mediated by CD28 stimulation, and is cyclosporine-resistant.

Correspondence to: C. H. June, Mail stop 44, Immunobiology and Transplantation Department, Naval Medical Research Institute, Bethesda, MD 20814, USA. 


\section{Introduction}

Interleukin-2 (IL-2) is a lymphocyte growth factor that is required for $\mathrm{T}$ cells to progress from $G_{1}$ into $S$ phase of the cell cycle [1]. According to the current paradigm, the messages provided by increased intracellular ionized calcium and protein kinase $C$ activation result in IL-2 gene activation [2-4]. Ligation of the T-cell antigen receptor and the associated CD3 complex, either by antigen or by monoclonal antibodies (MoAb), has been shown to cause both activation of protein kinase $\mathrm{C}$ and elevation of intracellular calcium [5,6]. However, there is accumulating evidence that stimulation of the $\mathrm{CD} 28$ antigen can activate resting $\mathrm{T}$ cells to proliferate via mechanisms that are distinct from the cytoplasmic messages generated after stimulation of the $\mathrm{CD} 3$ molecular complex.

In the present report we present evidence to suggest the existence of two distinct mechanisms of IL-2 gene regulation in peripheral blood T cells. Only small amounts of IL-2 mRNA were expressed after stimulation of cells by $\mathrm{CD} 3$, and in accord with previous studies [7-9], IL-2 production after CD3 stimulation was entirely prevented by cyclosporine. Direct elevation of intracellular calcium and activation of protein kinase $C$ by calcium ionophore plus phorbol ester treatment resulted in T-cell proliferation and IL-2 mRNA expression that was completely suppressed by cyclosporine. Similarly, proliferation after CD3 plus phorbol ester stimulation was prevented by cyclosporine. In contrast, proliferation induced by the CD28 pathway was found to be entirely resistant to cyclosporine, and furthermore, it was demonstrated that CD28-induced IL-2 expression is resistant to cyclosporine. Nuclear run-on transcription studies indicate that the mechanism of the CD28 signal is post-transcriptional and involves stabilization of lymphokine mRNA.

\section{Materials and methods}

Monoclonal antibodies

CD28 MoAb 9.3 (IgG2a) was purified on protein A-Sepharose, dialysed against phosphate-buffered saline, filtered through a $0.22 \mu \mathrm{m}$ sterile filter, and cleared of aggregates by centrifugation $(100,000 \times \mathrm{g}$ for $45 \mathrm{~min})$ prior to use in functional assays $[10]$.

\section{Cells}

Peripheral blood lymphocytes $\left(\sim 2.5 \times 10^{9}\right)$ were isolated from buffy coats obtained by leukopheresis of healthy donors aged 21 to 31 years using density gradient centrifugation. The $\mathrm{CD}^{+} 8^{+}$subset of $\mathrm{T}$ cells was then isolated from the PBL by negative selection using immunoabsorption as previously described [10].

\section{Proliferation assays}

Cells were cultured in quadruplicate samples in flat-bottom, 96-well microtitre plates at $5 \times 10^{4}$ cells per well in RPMI medium containing $5 \%$ heat-inactivated 
fetal calf serum (Hyclone, Logan UT). Cell proliferation was measured in a liquid scintillation counter after pulsing cells for the last $6-8 \mathrm{~h}$ of $3 \mathrm{~d}$ cultures with $1 \mu \mathrm{Ci} /$ well of ${ }^{3} \mathrm{H}$-thymidine (New England Nuclear Corp., Boston, MA, USA).

\section{Cell cycle analysis}

Cells were analysed for DNA content on an Ortho Cytofluorograph after staining with propidium iodide using a procedure described by Krishan [11]. The distribution of cells within the cell cycle was determined by the method of Dean and Jett [12].

\section{Uridine incorporation}

Incorporation of ${ }^{3} \mathrm{H}$-uridine $\left(5-6-{ }^{3} \mathrm{H}\right.$ uridine $47 \mathrm{Ci} / \mathrm{mmol}$, New England Nuclear) was used as a measure of total cellular RNA synthesis and of $G_{0}$ to $G_{1}$ cell cycle transition. Cells $\left(1 \times 10^{5} /\right.$ well $)$ were cultured for various durations and pulsed for the last $6 \mathrm{~h}$ with $1 \mu \mathrm{Ci} /$ well of tritiated uridine, and uridine incorporation determined on a liquid scintillation counter after the cells were collected on glass fibre filters.

\section{RNA (Northern) blot analysis}

$\mathrm{CD}^{2} 8^{+} \mathrm{T}$ cells were cultured at $2 \times 10^{6} / \mathrm{ml}$ in complete medium. The cells were harvested by centrifugation and total cellular RNA extracted using guanidinium isothiocyanate. The samples were equalized for rRNA, and the equalization confirmed by ethidium bromide staining of equal amounts of the RNA samples separated on a non-denaturing $1 \%$ agarose gel as described previously [10].

\section{DNA probes}

The ${ }^{32} \mathrm{P}$ probes used in these experiments were all the result of nick translation of gene-specific inserts ( 50 to $100 \mathrm{ng}$ ) isolated from low-melt agarose gels following digestion of the plasmid in which they were propagated with appropriate restriction endonucleases. The IL-2 specific probe is a $1.0 \mathrm{~kb}$ Pst I cDNA insert derived from the pTCGF5 plasmid obtained from S Arya [13]. The HLA B7 probe was a $1.4 \mathrm{~kb}$ Pst I fragment isolated from pHLA-B7 [14].

\section{Lymphokine assays}

IL-2 was measured by adding four five-fold dilutions of culture supernatants to quadruplicate wells containing $8 \times 10^{3}$ cells of the IL-2 dependent cell line CTLL-2 (American Type Tissue Collection, Rockville MD, USA [15]). Thymidine incorporation was determined after $24 \mathrm{~h}$ of culture and the data analysed by probit analysis. One unit was defined as the amount of IL-2 leading to half maximal proliferation. In some assays, IL-2 was measured using an ELISA (Genzyme Corp., Boston MA, USA). 


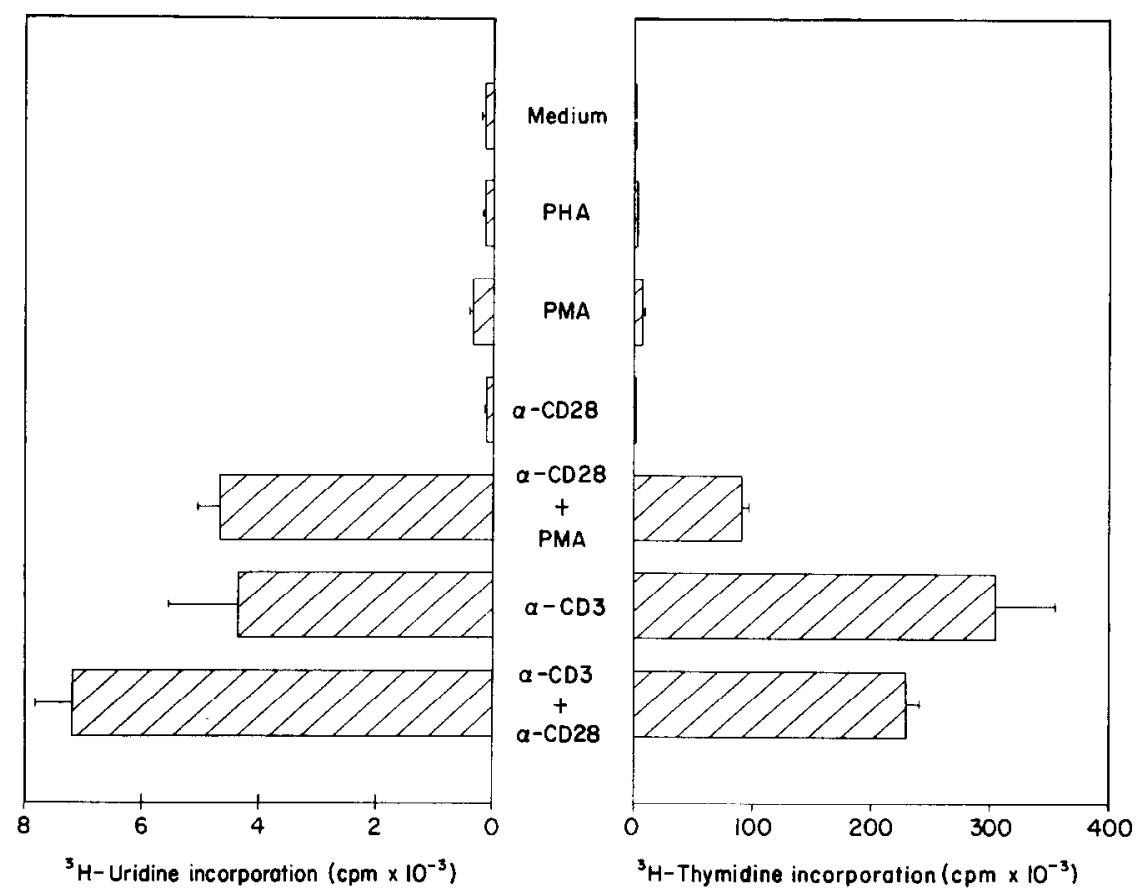

Figure 1. Effects of CD28 MoAb 9.3 and CD3 MoAb G19-4 on (a) RNA and (b) DNA synthesis. $\mathrm{CD}_{28}{ }^{+} \mathrm{T}$ cells $\left(1 \times 10^{5} /\right.$ well) were cultured in the presence of medium, PHA $10 \mu \mathrm{g} / \mathrm{ml}, \mathrm{PMA} 1 \mathrm{ng} / \mathrm{ml}$, CD28 MoAb $9.3100 \mathrm{ng} / \mathrm{ml}$, immobilized CD3 MoAb G19-4 200 ng/well. The cells were cultured for either $18 \mathrm{~h}$ and pulsed (a) for $6 \mathrm{~h}$ with $1 \mu \mathrm{Ci} /$ well tritiated uridine or (b) for $72 \mathrm{~h}$ and pulsed for $6 \mathrm{~h}$ with $1 \mu \mathrm{Ci} /$ well with tritiated thymidine and the mean plus 1 S.E.M. cpm of quadruplicate samples determined by liquid scintillation counting.

\section{Results}

\section{Effects of anti-CD28 and anti-CD3 stimulation on entry into the cell cycle}

Previous results indicated that stimulation of purified $\mathrm{CD} 28^{+} \mathrm{T}$ cells by anti-CD28 $\mathrm{MoAb}$ alone does not result in cell cycle progression, and that the CD28 signal synergizes with protein kinase $\mathrm{C}$ activation to cause cell size increases that were evident by $\sim 12 \mathrm{~h}$ after stimulation [10]. Stimulation of $\mathrm{CD}^{+} \mathrm{T}$ cells with immobilized CD3 MoAb has been shown by Geppart et al. [16] to cause proliferation that is independent of accessory cells. In addition, they found that anti-CD28 augmented the rate of proliferation only after stimulation with suboptimal and not optimal amounts of immobilized CD3 MoAb. CD28 ${ }^{+} \mathrm{T}$ cells were cultured in medium, MoAb 9.3, PHA, PMA with and without MoAb 9.3, and immobilized CD3 MoAb with and without $\mathrm{MoAb}$ 9.3, and were analysed for DNA synthesis on day 3 of culture. In addition, companion cultures were analysed simultaneously for uridine incorporation as an index of total cellular RNA synthesis (Figure. 1). Similar to Geppart et al. [16], we found that immobilized CD3 MoAb was mitogenic for purified $\mathrm{CD}_{28}{ }^{+} \mathrm{T}$ cells, and that the addition of soluble anti-CD28 to cells stimulated with optimal amounts of $\mathrm{CD} 3 \mathrm{MoAb}$ did not increase proliferation. After treatment of purified $\mathrm{CD}_{28}{ }^{+}$cells with PHA or PMA only, thymidine incorporation was only 
slightly above baseline, indicating that these reagents are co-mitogens for $T$ cells, and that for these reagents, 'accessory' cells (monocytes) are required to cause T-cell proliferation. Similarly, neither anti-CD28, PHA nor PMA alone were able to cause significant uridine incorporation after $24 \mathrm{~h}$ of culture. Under conditions associated with DNA synthesis (stimulation by immobilized $\mathrm{CD} 3 \mathrm{MoAb}$ and soluble antiCD28 MoAb plus PMA), increased uridine incorporation also occurred. However, in contrast to the effects on thymidine incorporation, the addition of CD28 MoAb to cells cultured with optimal amounts of immobilized CD3 MoAb G19-4, caused an $\sim$ two-fold augmentation in uridine incorportion over that after stimulation by CD 3 MoAb alone.

\section{$C D 28$ regulates $I L-2$ production that is rate limiting after $C D 3$ stimulation}

Cantrell et al. demonstrated that IL-2 is a progression factor that is necessary and sufficient for a major subset of $T$ cells to progress from the $G_{1}$ to $S$ phase of the cell cycle [1]. The results presented heretofore demonstrate that CD28 stimulation acts early in the cell cycle to increase total cellular RNA synthesis in conjunction with suboptimal to optimal amounts of CD3 stimulation, and that CD28 stimulation increases the rate of DNA synthesis only when CD3 stimulation is suboptimal. These observations are compatible with the hypothesis that IL-2 production from purified $\mathrm{T}$ cells may be rat limiting after $\mathrm{CD} 3$ stimulation. The next series of experiments explored whether or not the CD28 signal could regulate IL-2 production that might limit cell cycle progression after $\mathrm{CD} 3$ stimulation.

Northern blot analysis was used to characterize the kinetics of IL-2 gene expression after stimulation by optimal amounts of immobilized CD3 MoAb with or without CD28 stimulation. In addition, the supernatants from these cultures were also analysed for IL-2 content and the cells analysed for cell cycle progression (data not shown). Since rRNA increases in direct proportion to cell volume as cells progress through the cell cycle, each sample was equalized for the level of rRNA to avoid the measurement of mRNA variations attributable only to increases in cell volume. Northern blots were hybridized sequentially with probes specific for IL-2, and a Class I HLA gene used to serve as an mRNA probe for a constitutively expressed gene. IL-2 mRNA expresion was suprisingly low after $\mathrm{CD} 3$ stimulation and peaked at $6 \mathrm{~h}$ of culture; only small amounts of IL-2 could be detected in the culture supernatant $(5 \mathrm{U} / \mathrm{ml}$ at $24 \mathrm{~h}$ ) although vigorous proliferation occurred as $41 \%$ of cells were in the $\mathrm{S}$ phase of the cell cycle or beyond. In contrast, in cells stimulated with CD3 plus CD28, there was a $>30$-fold increase in mRNA expression that peaked at $6 \mathrm{~h}$ of culture and persisted to $24 \mathrm{~h}$ of culture. There was a comparable increase in IL-2 concentration in the culture supernatant $(>200 \mathrm{U} / \mathrm{ml}$ at $48 \mathrm{~h}$ ) from the CD3 plus CD28 condition although the percentage of cells in the $S$ phase or beyond of the cell cycle was similar to that after CD3 stimulation. HLA Class I mRNA expression was not affected by CD28 stimulation. Thus, these findings show that CD28 stimulation both sustains and substantially augments IL-2 production and secretion in conjunction with $\mathrm{CD} 3$ stimulation, and are consistent with the above results (Figure 1) that CD3 stimulation, resulting in only modest IL-2 expression, is sufficient for the entry into the first round of the cell cycle and the initiation of DNA synthesis in a comparable fraction of cells as occurs after stimulation by CD3 plus CD28. 
Table 1. Kinetics of $I L-2$ secretion after stimulation by anti-CD3 and anti-CD28 ${ }^{1}$

\begin{tabular}{|c|c|c|c|c|c|c|}
\hline \multicolumn{3}{|c|}{ Monoclonal antibody } & \multicolumn{4}{|c|}{$\begin{array}{c}\text { IL-2 production }(\mathrm{U} / \mathrm{ml}) \text { DNA synthesis }\left(\mathrm{cpm} \times 10^{-3}\right) \\
\text { Hours of culture }\end{array}$} \\
\hline Immobilizec & & Soluble & 6 & 12 & 36 & 48 \\
\hline CD3 G19-4 & $200 \mathrm{ng}$ & $\mathrm{Nil}$ & $<1$ & 13 & 7.4 & $62.9 \pm 11.4$ \\
\hline CD3 G19-4 & $200 \mathrm{ng}$ & $\mathrm{CD} 289.3$ & 5.1 & 170 & 670 & $23.7 \pm 4.6$ \\
\hline CD3 G19-4 & $50 \mathrm{ng}$ & Nil & $<1$ & 5 & 7.1 & $70.1 \pm 12.6$ \\
\hline CD3 G19-4 & $50 \mathrm{ng}$ & CD28 9.3 & 3.3 & 210 & 310 & $106 \pm 2.6$ \\
\hline CD3 G19-4 & $10 \mathrm{ng}$ & Nil & $<1$ & $<3$ & 2 & $24.3 \pm 8.1$ \\
\hline CD3 G19-4 & $10 \mathrm{ng}$ & CD28 9.3 & 1 & 170 & 310 & $193 \pm 8.9$ \\
\hline CD3 G19-4 & $4 \mathrm{ng}$ & Nil & $<1$ & $<1$ & $<1$ & $1.2 \pm 0.4$ \\
\hline CD3 G19-4 & $4 \mathrm{ng}$ & CD28 9.3 & $<1$ & 26 & 2.9 & $25.5 \pm 0.2$ \\
\hline
\end{tabular}

${ }^{1} \mathrm{CD} 28^{+} \mathrm{T}$ cells $\left(5 \times 10^{4} /\right.$ well) were cultured in quadruplicate in the presence of immobilized CD3 MoAb at the indicated concentration in the presence or absence of $\mathrm{MoAb} 9.3(1 \mu \mathrm{g} / \mathrm{ml})$ and dilutions of culture supernatants analysed for IL-2 content after $6-36 \mathrm{~h}$ of culture and thymidine incorporation (mean \pm 1 S.E.M.) determined after $72 \mathrm{~h}$ of culture.

To examine further the ability of CD28 to augment IL-2 production after CD3 stimulation, cells were cultured with suboptimal to optimal amounts of immobilized $\mathrm{CD} 3 \mathrm{MoAb}$ in the presence or absence of CD28 MoAb 9.3 and the supernatants assayed for IL-2 concentration at 6,12 , and $36 \mathrm{~h}$ of culture (Table 1 ). There was a 10-100-fold augmentation of IL-2 secretion by cells stimulated with anti-CD28 at all levels of CD3 stimulation, although DNA synthesis was increased by anti-CD28 only with conditions having suboptimal CD3 stimulation.

\section{CD28-induced $T$-cell proliferation is resistant to the effects of cyclosporine}

One explanation for the supoptimal IL-2 gene expression after CD3 stimulation is that even optimal amounts of CD3 stimulation result in suboptimal calcium and protein kinase $\mathrm{C}$ signals. Alternatively, it is possible that another distinct membrane signal, such as that provided by CD28, is required for optimal IL-2 expression following cell surface stimulation by antigen. It is also possible that CD3 stimulation is associated with both positive and negative effects, and that the $\mathrm{CD} 28$ signal functions to override the negative signal so that IL-2 secretion then resembles that induced by calcium ionophore plus phorbol ester. To distinguish between these possibilities, we investigated the effects of cyclosporine on CD28-induced activation, as there is evidence that one mechanism of action of cyclosporine is to prevent IL-2 gene expression $[9,17] . \mathrm{CD} 28^{+} \mathrm{T}$ cells were cultured with immobilized CD3 MoAb G19-4, immobilized CD3 MoAb plus CD28 MoAb, soluble CD3 MoAb plus PMA, CD28 MoAb plus PMA, and ionomycin plus PMA, alone and in the presence of increasing amounts of cyclosporine (Table 2). The above combinations of agonists were chosen because previous studics had shown that CD3 MoAbs alone in solution are not mitogenic for purified $T$ cells while the combination of PMA plus soluble CD3 or CD28 MoAbs is fully mitogenic $[9,18]$, and furthermore, on purified 
Table 2. Effects of cyclosporine on CD3 and CD28-mediated proliferation of $T$ cells ${ }^{t}$

\begin{tabular}{|c|c|c|c|c|c|c|}
\hline \multirow[b]{3}{*}{ Stimulus } & \multicolumn{5}{|c|}{ Thymidine incorporation $\left(\mathrm{cpm} \times 10^{-3}\right)$} & \multirow{3}{*}{ inhibition } \\
\hline & \multicolumn{5}{|c|}{ Cyclosporine $(\mu \mathrm{g} / \mathrm{ml})$} & \\
\hline & 0 & 0.2 & 0.4 & 0.8 & 1.2 & \\
\hline \multicolumn{7}{|l|}{ Exp. 1} \\
\hline CD3 G19-4 & $25.0 \pm 3.1$ & $15.3 \pm 0.9$ & $13.1 \pm 0.5$ & $2.6 \pm 0.4$ & $2.2 \pm 0.2$ & 92 \\
\hline $\mathrm{CD} 3+\mathrm{CD} 289.3$ & $30.9 \pm 2.3$ & $21.6 \pm 0.3$ & $15.8 \pm 0.6$ & $11.1 \pm 0.7$ & $10.7 \pm 0.6$ & 65 \\
\hline CD28 9.3+PMA & $27.7 \pm 1.5$ & $24.3 \pm 0.7$ & $26.8 \pm 1.5$ & $24.7 \pm 1.8$ & $28.0 \pm 0.3$ & $<0$ \\
\hline \multicolumn{7}{|c|}{ 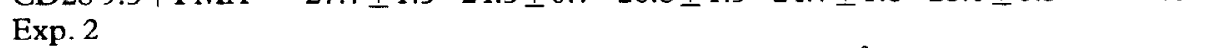 } \\
\hline CD3 G19-4 + PMA & $35.3 \pm 3.4$ & $4.8 \pm 0.4$ & $2.3 \pm 0.2$ & $\mathrm{ND}^{2}$ & ND & 93 \\
\hline CD28 9.3+PMA & $41.6 \pm 4.2$ & $39.6 \pm 5.2$ & $40.8 \pm 3.2$ & ND & ND & 2 \\
\hline PMA + Ionomycin & $19.7 \pm 1.7$ & $7.6 \pm 0.7$ & $3.7 \pm 0.4$ & ND & ND & 81 \\
\hline
\end{tabular}

'CD28-positive $\mathrm{T}$ cells were cultured as described in Materials and methods and thymidine incorporation (mean \pm 1 S.D.) was determined on day 3 of culture. In experiment 1 the conditions tested were: CD3 antibody adsorbed onto plastic; antibody $9.3100 \mathrm{ng} / \mathrm{ml}$; and PMA $1 \mathrm{ng} / \mathrm{ml}$; in experiment 2 the conditions were as above except that CD3 MoAb G19-4 was soluble at $1 \mu \mathrm{g} / \mathrm{ml}$ and ionomycin was $0.1 \mu \mathrm{g} /$ $\mathrm{ml}$. The percentage inhibition of proliferation was calculated between cells cultured in medium only $v s$ cyclosporine at $1.2 \mu \mathrm{g} / \mathrm{ml}$. (exp. 1) or $0.4 \mu \mathrm{g} / \mathrm{ml}$ (exp. 2). Cells cultured in the absence of cyclosporine were given cyclosporine diluent. Thymidine incorporation of cells cultured in medium, PMA, or MoAb 9.3 only was $<150 \mathrm{cpm}$.

${ }^{2}$ Not done.

T cells, soluble CD28 MoAb augments the effects of immobilized and not soluble CD3 MoAbs. Previous studies have shown that T-cell proliferation induced in PBL with soluble MoAbs to the $\mathrm{CD} 3 / \mathrm{T}$-cell receptor complex is sensitive to cyclosporine with an $\mathrm{ID}^{50}$ of $\sim 25 \mathrm{ng} / \mathrm{ml}$ [7-9]. We confirmed those results (not shown) and found that proliferation induced in purified $\mathrm{T}$ cells by immobilized $\mathrm{CD} 3 \mathrm{MoAb}, \mathrm{CD} 3$ MoAb plus PMA, or ionomycin plus PMA was also sensitive to cyclosporine. In contrast, proliferation induced by the CD28 plus PMA pathway was entirely resistant to cyclosporine, even at $1.2 \mu \mathrm{g} / \mathrm{ml}$ (Table 2). The resistance of T cells to cyclosporine after $\mathrm{CD} 28$ plus phorbol ester treatment was reproduced using lymphocytes from more than 10 different donors, indicating that the resistance to cyclosporine of $T$ cells stimulated in this manner does not reflect individual variation. When cells were cultured with immobilized $\mathrm{CD} 3 \mathrm{MoAb}$ plus $\mathrm{CD} 28 \mathrm{MoAb}$ 9.3, an intermediate level of sensitivity to cyclosporine was found (Table 2).

\section{Distinct effects of cyclosporine on CD28 and on calcium ionophore plus phorbol ester-induced IL-2 $m R N A$ expression}

Given the result that T-cell proliferation induced by $\mathrm{CD} 28$ stimulation may be partially or entirely resistant to cyclosporine, Northern blots were prepared to determine the effects of cyclosporine on CD28-induced IL-2 mRNA expression. CD28 ${ }^{+}$ cells were stimulated with either CD28 MoAb 9.3 plus PMA, with immobilized CD3 MoAb G19-4 \pm MoAb 9.3, in the presence or absence of cyclosporine (Figure. 2). 

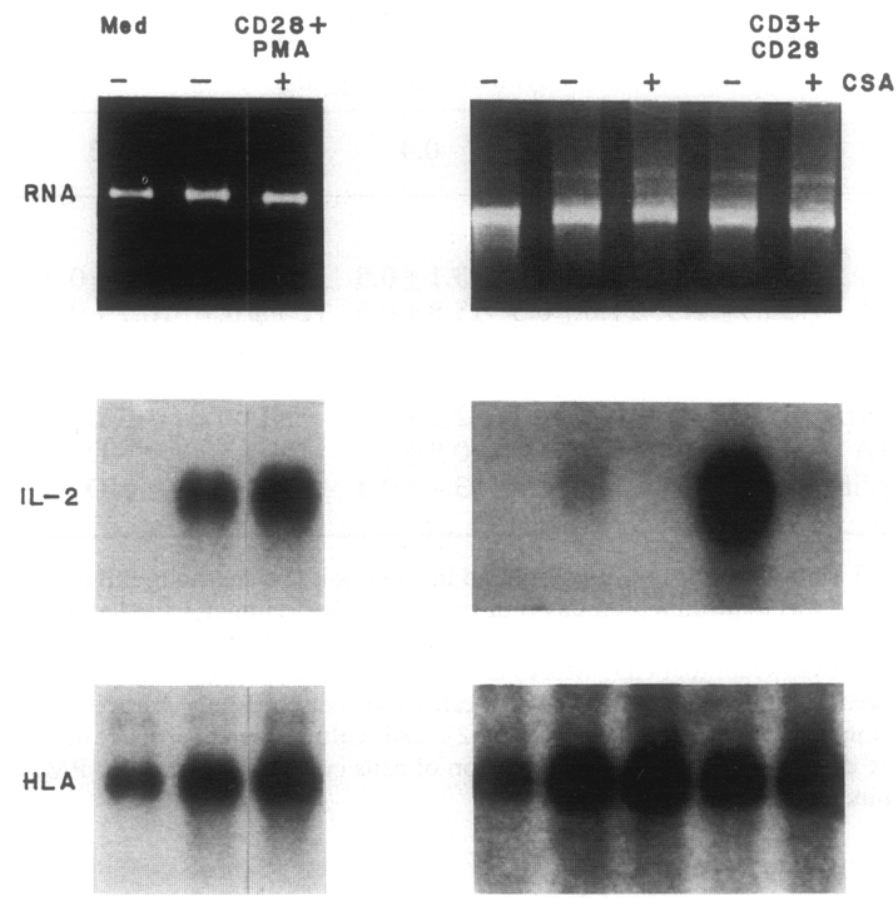

Figure 2. Effects of anti-CD28 stimulation on IL-2 mRNA expression, IL-2 secretion, and cell cycle progression. $\mathrm{CD} 28^{+} \mathrm{T}$ cells were cultured with medium (MED), CD3 MoAb G19-4 immobilized to plastic, or immobilized CD3 MoAb plus CD28 MoAb $9.3(1 \mu \mathrm{g} / \mathrm{ml})$. The cells were harvested after 1,6 , 12 , or $24 \mathrm{~h}$ of culture and total cellular RNA isolated and equalized for rRNA. The equalization was confirmed by ethidium bromide staining of $10 \%$ aliquots of each RNA sample separated on a nondenaturing $1 \%$ agarose gel (upper panel). Northern blots were hybridized sequentially with IL-2 and HLA Class-I-specific cDNA probes. In addition, supernatants were analysed for IL-2 content by ELISA, and cell cycle distribution was measured after $48 \mathrm{~h}$ of culture by staining with propidium iodide and analysis by flow cytometry.

There was full expression of IL-2 mRNA in cells cultured for $12 \mathrm{~h}$ with 9.3 plus PMA in the presence of cyclosporine at $1 \mu \mathrm{g} / \mathrm{ml}$ (Figure 2, left panel); previous results showed that the time course of IL-2 mRNA expression under these conditions was identical in cells treated with cyclosporine compared with those cultured in the absence of cyclosporine [10]. Only minimal amounts of IL-2 mRNA were induced in CD3-stimulated cells in comparison to CD28 plus PMA-stimulated cells, and this induction was completely prevented by cyclosporine (Figure 2, right panel). The addition of soluble CD28 MoAb 9.3 to cells stimulated by immobilized CD3 caused a marked enhancement of IL-2 mRNA expression, and in contrast to the CD28 plus PMA system, the IL-2 production of cells cultured with CD3 plus CD28 $\mathrm{MoAb} 9.3$ was partially inhibited by cyclosporine, although the cells stimulated with CD28 plus CD 3 in the presence of cyclosporine had equivalent amounts of IL-2 mRNA as cells cultured in the absence of the drug and stimulated by immobilized CD3 only. IL-2 mRNA expression of cells stimulated by calcium ionophore plus 
phorbol ester was similar in magnitude to that of cells stimulated with CD28 plus CD3, but in contrast, was completely inhibited by cyclosporine (not shown), similar to cells cultured with CD3. Transcripts hybridizing with the HLA Class I gene were detectable at equivalent levels in all conditions tested, excluding non-specific degradation of mRNA as an explanation for the failure to detect IL-2 mRNA in the cyclosporine-sensitive conditions.

\section{Discussion}

The foregoing studies analysed the effects of CD3 and CD28 stimulation of resting $\mathrm{T}$ cells on cell cycle entry and IL-2 gene expression. Stimulation by optimal amounts of $\mathrm{CD} 3$ or by $\mathrm{CD} 3$ plus $\mathrm{CD} 28$ was found to cause equivalent levels of proliferation as assayed by DNA synthesis. However, there were striking differences in IL-2 secretion. CD3 stimulation caused only small amounts of IL-2 to be produced for a brief duration, while CD3 plus CD28 caused substantial augmentation and prolongation of total cellular RNA synthesis and IL-2 secretion. These results are the first example of IL-2 production within a single population of cells that may be either sensitive or resistant to cyclosporine, depending on the form of stimulation, and suggest that CD28 regulates IL-2 gene expression in a manner that differs biochemically from IL-2 expression induced after $\mathrm{CD} 3$ or calcium ionophore plus protein kinase $C$ stimulation. In preliminary experiments (not shown), the CD28 signal appears to regulate the stability of the lymphokine mRNA, and thus to act at a post-transcriptional level. In contrast, results from nuclear run-on transcription assays indicate that the signals provided by $\mathrm{CD} 3$ (calcium and protein kinase $\mathrm{C}$ activation) cause transcriptional activation of lymphokine expression, yielding mRNA that has a short half-life.

In the present study we found only small amounts of IL-2 mRNA were produced in cultures of purified $T$ cells stimulated with $C D 3$, and that $C D 28$ both prolonged and caused a striking augmentation of IL-2 mRNA expression in cells stimulated with CD3. If the barely detectable levels of IL-2 mRNA after CD3 stimulation indicate that IL-2 production is not rate limiting and signify that the amount of IL-2 that is necessary for one round of cell cycle proliferation in an autocrine fashion is quite small, then our results suggest that the role for CD28 may be to augment IL-2 production and to recruit cells via a paracrine as well as an autocrine mechanism. The function of CD28 would be to amplify and sustain a response that was initiated in an antigen-specific manner in vivo by up-regulation of IL-2 production. Alternatively, the minimal amounts of IL-2 mRNA expressed after stimulation by immobilized CD 3 antibodies in the absence of the $\mathrm{CD} 28$ signal could indicate that CD3/T-cell receptor-induced proliferation is primarily dependent upon growth factors other than IL-2, such as IL-4 [19], and that the CD28 pathway regulates an IL-2 dependent system.

T-cell proliferation induced by CD28 plus PMA was entirely resistant to cyclosporine, in contrast to the sensitive pattern that we found for immobilized CD3 $\mathrm{MoAb}$, and that others have reported previously for soluble CD3 MoAb and the lectins phytohemagglutinin and concanavalin $A[7-9,20]$. An intermediate result was found with CD28 plus CD3/T-cell receptor-induced proliferation; both the rate of proliferation and IL-2 mRNA expression were decreased $\sim 25 \%-75 \%$ by 
cyclosporine, depending on the lymphocyte donor. In addition we have found that CD28 stimulation confers resistance to the antiproliferative effects of glucocorticiods (data not shown). Thus, the CD28 pathway is able to overcome the effects of several distinct immunosuppressants, suggesting that the CD28 pathway may have an important role in vivo in $\mathrm{T}$-cell proliferation that is resistant to currently available immunosuppressants. Together, the present results suggest that the CD28 pathway activates a major subset of T cells to proliferate via an IL-2 dependent mechanism that is biochemically distinct from CD3.

\section{Acknowledgements}

We thank Nancy Craighead for excellent technical assistance, Mr Douglas Smoot for flow cytometry, the Blood Bank of the Naval Hospital for leukapheresis, Drs S. Arya, J. Danska and J. Bell for gifts of cDNA probes, and Dr H. J. Deeg for the gift of cyclosporine.

\section{References}

1. Cantrell, D. A. and K. A. Smith. 1984. The interleukin-2 T-cell system: a new cell growth model. Science (Wash. DC) 224: 1312

2. Weiss, A., R. L. Wiskocil, and J. D. Stobo. 1984. The role of T3 surface molecules in the activation of human $\mathrm{T}$ cells: a two-stimulus requirement for $\mathrm{IL-2}$ production reflects events occurring at a pretranslational level. f. Immunol. 133: 123

3. Truneh, A., F. Albert, P. Golstein, and A. Schmitt-Verhulst, 1985. Early steps of lymphocyte activation bypassed by synergy between calcium ionophores and phorbol ester. Nature (Lond). 313: 318

4. Weiss, A., J. Imboden, K. Hardy, B. Manger, C. Terhorst, and J. Stobo. 1986. The role of the $\mathrm{T}$ 3/antigen receptor in $\mathrm{T}$-cell activation.

5. Shapiro, D. N., B. S. Adams, and J. E. Niederhuber. 1985. Antigen-specific T cell activation results in an increase in cytoplasmic free calcium. 7 . immunol. 135: 2256

6. Imboden, J., C. Weyand, and J. Goronzy. 1987. Antigen recognition by a human T cell clone leads to increases in inositol trisphosphate. F. Immunol. 138: 1322

7. Ferrini, S., A. Moretta, R. Biassoni, A. Nicolin, and L. Moretta. 1986. Cyclosporin-A inhibits IL-2 production by all human $\mathrm{T}$-cell clones having this function, independent of the T4/T8 phenotype or the coexpression of cytolytic activity. Clin. Immunol. Immunopath. 38: 79

8. Kay, J. E. and C. R. Benzie. 1986. Lymphocyte activation by OKT3: cyclosporine sensitivity and synergism with phorbol ester. Immunology 57: 195

9. Granelli-Piperno, A., L. Andrus, and R. M. Steinman. 1986. Lymphokine and nonlymphokine mRNA levels in stimulated human $T$ cells. Kinetics, mitogen requirements and effects of cyclosporine A. F. Exp. Med. 163: 922

10. June, C. H., J. A. Lebetter, M. M. Gillespie, T. Lindsten, and C. B. Thompson. 1987. $T$-cell proliferation involving the $\mathrm{CD} 28$ pathway is associated with cyclosporine-resistant interleukin 2 gene expression. Mol. Cell. Biol. 7: 4472

11. Krishan, A. 1975. Rapid flow cytofluorometric analysis of mammalian cell cycle by propidium iodide staining. F. Cell. Biol. 66: 188.

12. Dean, P.N. and J. H. Jett. 1974. Mathematical analysis of DNA distribution derived from flow cytometry. F. Cell. Biol. 60: 523

13. Clark, S. C., S. K. Arya, F. Wong-Staal, M. Matsumoto-Kobayashi, R. M. Kay, R. J. Kaufman, E. L. Brown, C. Shoemaker, T. Copeland, S. Oroszlan et al. 1984. Human T-cell growth factor: partial amino acid sequence, cDNA cloning, and organization and expression in normal and leukemic cells. Proc. Natl. Acad. Sci. USA 81: 2543 
14. Sood, A. K., D. Pereira, S. M. Weissman. 1981. Isolation and partial nucleotide sequence of a cDNA clone for human histocompatibility antigen HLA-B by use of an oligodeoxynucleotide primer. Proc. Natl. Acad. Sci. USA.78: 616

15. Gillis, S. and K. A. Smith. 1977. Long term culture of tumour-specific cytotoxic T cells. Nature (Lond.) 268: 154

16. Geppert, T. D. and P. E. Lipsky. 1987. Accessory cell independent proliferation of human T4 cells stimulated by immobilized monoclonal antibodies to CD3. F. Immunol. 138: 1660

17. Kronke, M., W. J. Leonard, J. M. Depper, S. K. Arya, F. Wong-Staal, R. C. Gallo, T. A. Waldmann, and W. C. Greene. 1984. Cyclosporin A inhibits T-cell growth factor gene expression at the level of mRNA transcription. Proc. Natl. Acad. Sci. USA 81: 5214

18. Hara, T. and S. M. Fu. 1985. Human T cell activation. I. Monocyte-independent activation and proliferation induced by anti-T3 monoclonal antibodies in the presence of tumour promoter 12-o-tetradecanoyl phorbol-13 acetate. F. Exp. Med. 161: 641

19. Spits, H., H. Yssel, Y., Takebe, N. Arai, T. Yokota, F. Lee, K. Arai, J. Banchereau, and J. E. Devries. 1987. Recombinant interleukin 4 promotes the growth of human T cells. $\mathcal{F}$. Immunol. 139: 1142

20. Weisinger, D. and J. F. Borel. 1979. Studies on the mechanism of action of cyclosporin A. Immunobiology 156: 454 